\title{
Sali Bytyçi, The Poet -Who Looks for The Symbol of Spirit's Written in Verse
}

\author{
Prof. Ermelinda Kashahu
}

"E'qremCabej" University, Argiro, Albania

\section{Doi:10.5901/ajis.2014.v3n4p339}

\begin{abstract}
The human imagination of this author sends me far, very far, in the war of Troy, where a simple warrior, Thersites, while speaking about the real intentions of the chiefs, was hit behind his back by Odysseus in his scepter. This way, Thersites in the lliad is called because he has been rancorous because he has the admiration of the human generations. The same thing happens here. The model of writer is created which is not only read, but it is devoured like none else. The literary aspect, ideologically and emotionally, conducts to me these changes, in times of changes and different expectations which are reflected in poetry, which despite being censored to a certain extent; it still exhibits ideas, emotions and artistic values. The author exploits an obvious number, rare words, with instruments of distinguishing stylistic colorations, of thoughts and feelings, because he uses language with an extraordinary accuracy, for example: in the poem entitled: "When they punish the poet", we meet the expression of the strengthened role, rhythm and poetic form. Based on the way of the use of linguistic matter, rhythmic building of the verse, kinds of stanzas, I reinforce my opinion that: the poet is a creator of assigned theoretical knowledge for poetry.
\end{abstract}

Keywords: evocation, feeling, poetry, verse, pain.

\section{Introduction}

The idea to Write this essay analyse model, about this interesting writer and poet, it came to my mind a long time ago.Not only to that one as a token friendship of us, but particularly commiting the cordial talks to paper, that really worthwhile. That, it wouldn' be fully sufficient, ifl wouldn't have been followed his literary works at the throng of at all events of his life, that kept company with the poet. Sali Bytyçi was born in Deja village of Drenica. He graduated university, major Language and Literature in University of Prishtina.Kosovo poet has been persecuted since 1981 and the going on years, he has been convicted of penal prosecution carrying on political agitation and propagation. In 1998, poet was taken hostage by Serbian forces and held in various prisons for about thirty months. The albanian society has been affected emotionally by the fate of rebel writer, dominating with full knowledge of the political facts at times and sometimes at literary work, where the first one was imposed by the system and the other one was prevailing by the others. In proportion to exchange of two realities, it reminds me the verse of our folk -song:- "Bend the back, let's coming out of the moon"! Because of that time, it's being in doubt for not respecting method experiences. Sali Bytyçi has not been commited at political service of that time, that other people did diligently and the grudges were nursing against him in everytime. By all means, Sali Bytyçi, it's the author, who has been going through the painful yesterday's, no confident of it, and his life was put at stake, just as Greek goddesses, that come out of hazy time in their last moments, saving the heroes and protecting the writer. But the writer has gained the referring experience, where in most instances, they were bearing witness themselves and the time that they were eye-witnessing, too. Interesting!Sometimes the man is forcible to confront to the unpersonality crowd, and sometimes we are being dominated by the disinherited class of the untimely. It seems like the forest is shrubbed. He and bureaucracy of era were sitting cross-legged, but the "enslaving pen" couldn't get rid of a free writing pen. The best- rivered culture of the author, a streamlet comes out of the spiritual source and streams on the breeze, becoming healthy and wealthy, watering the civilization tree to get its oën free will. The great literary works'structure, healthy brain and talented skills that never get tired ofand it makes me feeling excited at the thought. According to the productive literary univers and confusion matters, the real artistic values of a sound mind in a sound body gleam his literature personality towards the highest summits of art, culture and civilization. The adaptability oh his kind origin, specific nature and excellent general knowledge, that it takes everyone by surprise and admires the arrival of the lacking, the poet of era, the sense of albanians'pride, it's appealing to regain the lost time and his civil statute.Intelligent, evident, sensible, witty and irresistible against the abusive values.He is a respected and admired connoisseur with profound knowledge of ancient culture and new ones, -a unique and a very successful poet and writer with great skills and the victory smiles on other cultures. As poet and intellectual, the symbol of spirit and human, Sali 
Bytyçi is a prognosticative and creative man.

\section{The impressions and deep imprints left by his poetry:}

I am citing some poetic verses, that shudder my spirit. I am feeling anxious, sluggard, numbness and my heart is throbbing. Just a tiny bit mixed with the muse of poet, it calms me and heals the pain, reaching settlement of my spirit. I think, the instinct of poet is alive!

"Every time I think of you"

(To my wife Drita)

${ }^{*}$ Every time I think of you, In front of my eyes I picture ancient Penelope, And I am Ulysses roaming in the endless sea, Every time I think of you, In my eyes it's a beautiful woman, waiting forever at home

And I am the soldier who is longing beyond The Bridge of Kabaa"

The communist regime hurted him morally and spiritually, the poet and writer who's giving the best to the literature. The literary spirit of his poetry presents esthetic beauty, realistic observations, coeval and cultural vision. His affinity to poetry is brilliant. Some of his poems are a solid metaphor, which is placed inside the reflex of light, it comes out of its spiritual source an getting brightness from the sun. His consequence propensitynot only displays his stylistic figuration, but also other effects of the rhythmic nature and sonourous one.After the tiring and long path to realise and tell the frozen truth for that truth, his poetry floats his human and beautiful thoughts. His poetic verses are emblematic decorum of ideas, the intensity that is coming out of shade and so-called black comic ëell. Part of this system is the function of key ëords, it is argumented by thematic pane and structure.The poetic verse carries all human experiences and the poet sees embodied values civilizations centuries. We see that feels double emotional experience of the reader.Symbol of spirit is the poetry uninterrupted way, maintaining by monotony. It is the recycle model of a missionary writer, that is to say leading to the reader. The internal energy is accumulated to win the battle with literature, identifying the weaver cloth of its artistic language. This poem is a natural talent explosion and provides a universal context to convey the reader to the idea of a space. Some of his poems are love- feelings, that it gets cosmic proportions. This feeling is so deep with ancient poetic motif and the author manages to deal with a lyrical,modern and poeticsensibility. We can tell that poet writes with a sense of personal dignity, presenting what he feels and keeps in his soul .

Keywords In this essay-analyse of literary text, it is very important to define the words, aiming to build their typology in the creativity structure of an author, demonstrating the features of individuality. The poem, which is titled: " You love me with no heart ", it evokes human pain .

Let's quote the verses :

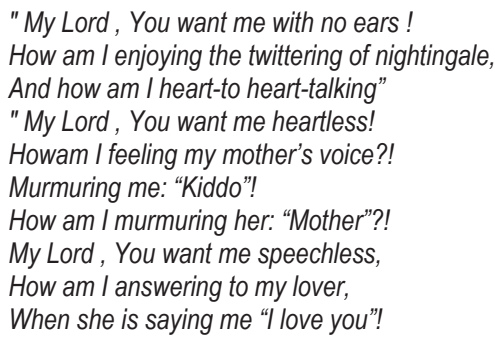

The dark feelingshas given the deepest anxietyto poet. He knows what is the life and death! The deluge of memories, when cruel hours of this suffered life involves contemporary, it gains the quotes of a meditation, love, light, life and happiness. It is cry of the soul, the story of a man who knows what is true love, the story of allegiance to those ideals 
which he served and helped to overcome the pain and live the life from the beginning. He's strongly associated with those that kidnapped the freedom, but it failed to allocate any moment by the reality of the poet.Sali Bytyçi's conscience never fall asleep, but it slipped from memories to memories. His own conscience turns his head from his calm face expressionar. He still is not trusting on the reality. He walked forever, not turning back. Because of walking, it doesn't mean just throwing legs, but live alive for the next generation.

\section{References}

Requiem for the lists, poems, Art Pena, Prishtinë, 1994

Labyrinths of the literary texts, (a book with critic points of view), Sheshi, Prishtinë 2003

In Medias recessions, Prishtinë, 2007

Florid and zoomorphic symbols in Albanian poetry (1945-2000), Monograph, Albanian Institute Prishtinë, 2008

"The day you carry in vain on your back", published in: Publishing House "Embeta", Prishtinë 2014. 
